\title{
Impact of fisheries on activity, diet and predatory interactions between yellow-legged and Audouin's gulls breeding at the Chafarinas Islands*
}

\author{
JACOB GONZÁLEZ-SOLÍS \\ Dept. Biologia Animal (Vertebrats), Av. Diagonal 645, Barcelona 08028, Spain. E-mail: jacob@bio.ub.es
}

\begin{abstract}
SUMMARY: Interactions between yellow-legged Larus cachinnans and Audouin's Larus audouinii gulls and fisheries operating around the Chafarinas Islands, located $4.5 \mathrm{~km}$ off the Moroccan Mediterranean coast, are reviewed. At the Chafarinas archipelago two distinct types of fisheries operate: trawlers and purse seines. Gulls take advantage of both fisheries. They scavenge trawler discards and congregate around shoals of fish attracted to the surface by the purse-seine lamps. When both trawlers and purse-seine boats are in operation, the diet of both gull species is similar, with epipelagic fish accounting for over $60 \%$ of the biomass, partially collected in association with the purse-seine fishery. When only trawlers operated yellow-legged gulls, but not Audouin's gulls, augmented their diet mainly with human waste from refuse dumps, suggesting that competition for food between the two species is mainly limited to the periods when resources made available by fishery activities are abundant. Likewise, when only trawlers operated, there was an increase in the predation pressure on eggs and chicks of Audouin's gulls. In particular, during the week of celebrations for the holy lamb festival when neither fishery operated, egg losses of Audouin's gull increased dramatically, suggesting that severe food shortage caused by the cessation of fishing can result in an increased predation pressure by yellow-legged gulls, affecting Audouin's gull productivity. These results suggest a novel socio-ecological link between gulls, fisheries and local feasts.
\end{abstract}

Key words: chick and egg predation, competition, diet overlap, purse seine boats, scavenging, seabird-fisheries interactions, trawler discards.

RESUMEN: IMPACTO DE LAS PESQUERÍAS SOBRE LA ACTIVIDAD, DIETA Y LAS INTERACCIONES PREDADORAS ENTRE LA GAVIOTA DE Audouin Y la PATIAMARILLA EN LAS ISLAS ChafarinaS. - En este trabajo se revisan las interacciones entre la gaviota patiamarilla Larus cachinnans, la gaviota de Audouin L. audouinii y las pesquerías comerciales que faenan en los alrededores de las islas Chafarinas. En dichas islas, situadas frente a la costa marroquí, faenan dos tipos de pesquerías, los arrastreros y las traiñas o sardineras. Las gaviotas explotan ambas pesquerías, aprovechando los descartes de pescado de los arrastreros o localizando los bancos de pequeños pescados epipelágicos atraídos a la superficie por las lámparas de las traiñas. Cuando tanto los arrastreros como las traiñas faenaron, ambas especies de gaviota mostraron una composición de la dieta similar, con una proporción de pescado epipelágico por encima del $60 \%$ en biomasa, en parte obtenido en asociación con las traiñas. Cuando solo faenaron los arrastreros, las gaviotas patiamarillas, pero no las de Audouin, complementaron la dieta principalmente con desperdicios provenientes de los basureros. Estos resultados sugieren que la competencia por el alimento entre ambas especies de gaviota se limita principalmente a los periodos de sobreabundancia de recursos relacionados con las actividades pesqueras. Asimismo, cuando solo faenaron los arrastreros se incrementó la presión de predación sobre huevos y pollos de gaviota de Audouin. En particular, durante la semana de la fiesta del cordero, cuando ningún tipo de pesquería faenó, las predación sobre huevos de gaviota de Audouin se incrementó dramáticamente, lo que sugiere que la escasez de alimento provocada por la parada de las pesquerías puede propiciar un incremento de la predación de la gaviota patiamarilla y afectar a la productividad de la gaviota de Audouin. Estos resultados revelan una novedosa relación socio-ecológica entre las gaviotas, las pesquerías y las fiestas religiosas.

Palabras clave: predación de pollos y huevos, competencia, solapamiento de la dieta, traiñas, interacciones pesquerías y aves marinas, descartes de arrastreros.

*Received July 3, 2001. Accepted September 8, 2002. 


\section{INTRODUCTION}

Audouin's Larus audouinii and yellow-legged gull Larus cachinnans michahellis breed syntopically in several localities throughout the Mediterranean Sea, which greatly facilitates competition and interactions between the two species. On the Chafarinas Islands, both species form breeding colonies adjacent to each other. Yellow-legged gulls have undergone a widespread population increase in the western Mediterranean during the last decades, causing diverse detrimental effects on fauna and flora (Vidal et al., 1998). At the Chafarinas Islands, the increase in yellow-legged gulls has coincided with a decline in Audouin's gull numbers, and this resulted in a culling program at this site from 1987 to 1993 (Alvarez, 1992). This programme apparently reversed the population trends for both species, so that by 1994 numbers of Audouin's gulls were double those of yellow-legged gulls (Fig. 1). Since then, the yellow-legged gull colony has increased steadily until the present. Audouin's gull is thought to be a specialised nocturnal predator, feeding mainly on shoals of epipelagic fish, mostly clupeoids (Witt et al., 1981). However, most of the world population currently exploits resources associated with human fisheries (Oro, 1998; Pedrocchi et al., 2002; Arcos et al., 2001). Fishery activities, particularly trawling, have been shown to affect diet, activity patterns and reproductive parameters of Audouin's gulls at the Ebro Delta (Oro, 1995; Oro et al., 1996a; Oro et al., 1996b; Oro et al., 1997). The yellow-legged gull has

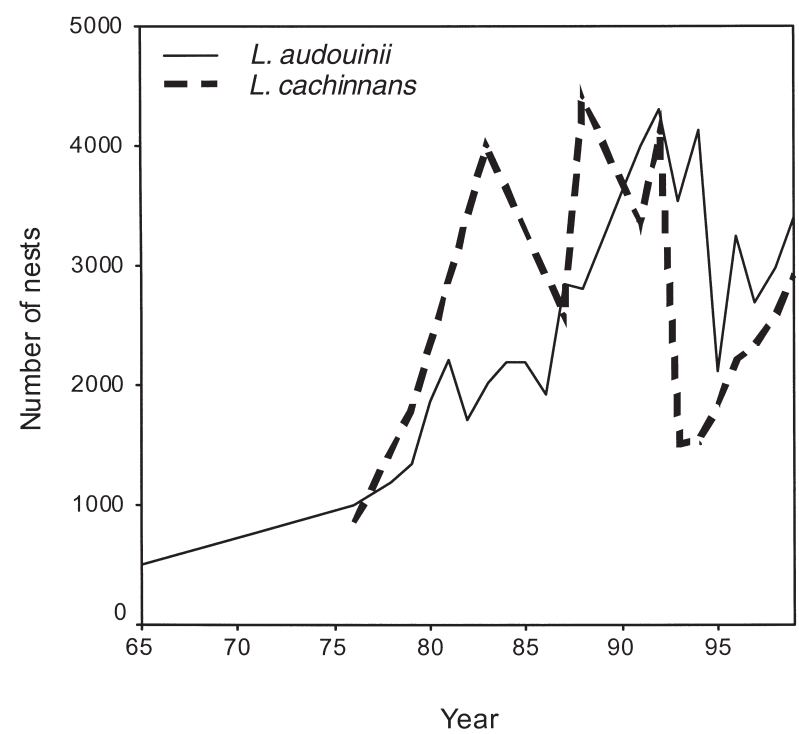

FIG. 1. - Population trends of Audouin's (L. audouinii) and yellowlegged (L. cachinnans) gulls at the Chafarinas archipelago. Culling programme of yellow-legged gulls was performed from 1987 to 1993. indicated that it is an opportunistic species relying heavily on human waste from refuse dumps and offal from commercial fisheries (Bosch et al., 1994; Bosch et al., 2000; González-Solís et al., 1997a; Munilla, 1997). A two-month trawling moratorium also affected diet and productivity of this species at the Ebro Delta (Oro et al., 1996b). Kleptoparasitism on adults, courtship and chick feedings as well as predation of eggs, chicks and occasionally adults of Audouin's gull have been reported at the two main colonies, that is, the Ebro delta and Chafarinas Islands (Oro, 1998). Thus, where these two species and commercial fisheries coexist we can expect changes in their feeding ecology and interactions in relation to fishery activities.

\section{MATERIAL AND METHODS}

Fieldwork was carried out during the breeding seasons of 1993, 1994 and 1995 at Chafarinas Islands, the second largest breeding site of Audouin's gull in the world.

\section{Study area and operating fisheries}

Chafarinas is a volcanic archipelago composed of three small islands (total area 53 ha) located 3.5 $\mathrm{km}$ off the Moroccan Mediterranean coast and 46 $\mathrm{km}$ east of Melilla city. Most Audouin's gulls breed at Rey Island and most yellow-legged gulls breed at Congreso Island, about $400 \mathrm{~m}$ apart.

At the Chafarinas, both purse-seine and trawler commercial fisheries operate near the islands. In the 1990s, there was a purse-seine fleet of about 14 boats operating around the islands. Most of boats were mainly from the port of Ras el Ma situated just in front of Chafarinas Islands. Purse-seine boats operate at night and at dawn, catching epipelagic fish attracted to the surface by powerful lamps, around which shoals of fish concentrate. Offal discharge from this fishery is minimal, but lamps aid the gulls in locating fish, particularly when the net is being hauled (Arcos and Oro, 2002). This fishery operates every night, except on Thursdays, on local religious celebrations and in bad weather conditions. The activity of the purse-seine fleet was assessed from the daily catch statistics from the bulletins of the fishermen's guild of Ras el Ma.

In contrast, trawlers operate continuously all year round, only stopping in very bad weather conditions. Trawlers often discard large amounts of fish by- 
catch, which is intensively exploited by gulls. There is an important fleet of about 40 trawlers in Nador harbour, about $45 \mathrm{~km}$ west of the Chafarinas archipelago, but only a few boats operate around the islands.

Thus, according to the activity of the purse-seine fleet registered at the harbour of Ras el Ma (days with and without catches), two levels of food availability can be delimited: (1) normal (about $60 \%$ of days), when purse-seine and trawler fisheries operate, and (2) reduced (about $40 \%$ of days) when only trawlers or neither fishery operate due to very bad weather conditions. This distinction has been used throughout this study to compare activity patterns, diet composition and predatory interactions of the yellow-legged gull and the Audouin's gull, between days with normal and with reduced food availability.

Exceptionally, a third level of food availability could be identified when not only purse-seine boats but also trawlers cancelled their operations due to the holy lamb festival celebrated in Muslim countries. This exceptional situation can be regarded as representing severe food shortage conditions for gulls and took place during one week in 1994 and in 1995, coinciding with the incubation period of the Audouin's gull. This third level of severe food shortage conditions was considered in this study only to investigate the potential impact of yellow-legged gull predation upon Audouin's gull eggs.

\section{Patterns of activity}

We analysed the daily activity cycles by counting the number of adults that remained at the colony site at two-hour intervals, either by naked eye from a hide or by using a telescope. Censuses were performed during the daylight, from 6:00 to 18:00 G.M.T. The results of counts were standardised to the largest number of birds observed and compared by performing Mann-Whitney tests on the average increment for each time interval (see details in González-Solís et al., 1999).

\section{Diet composition}

To study the diet composition of gulls, we collected regurgitates of chicks, since regurgitates constitute the least biased food sample for diet analysis (González-Solís et al., 1997b). To ensure independence among samples, only one fresh regurgitate from a chick per brood and nest was collected. Samples were classified depending on the activity of the purse-seine fleet. Prey categories were established according to an ecological typology and diet composition expressed in percentage of dry weight biomass. Typological groups were based on prey characteristics, which involved different hunting behaviour, predation effort or foraging habitats, resulting in four categories: (1) epipelagic preys caught in their natural environment or in association with purse-seine fisheries; (2) benthic-mesopelagic preys obtained from trawler discards; (3) terrestrial preys obtained on land; and (4) preys obtained at refuse tips (see details in González-Solís et al., 1997a).

\section{Direct observations on the Audouin's gull subcolonies}

A total of $424 \mathrm{~h}$ of direct observation on Audouin's gull subcolonies were carried out from a hide to analyse the influence of purse-seine activity on the frequency and intensity of interactions between yellow-legged gulls and Audouin's gulls. Five different types of interactions were considered: (1) flyovers of yellow-legged gulls on Audouin's gull subcolonies; (2) ground intrusions; (3) egg predation; (4) chick predation; and (5) aerial kleptoparasitism. Moreover, each aerial intrusion of yellowlegged gull above the Audouin's gull subcolonies was recorded, as well as whether or not this intrusion elicited an agonistic response by the Audouin's gulls. To analyse the frequency of the events according to normal or reduced food conditions, events were classified according to activity of the purseseine fleet (see details in González-Solís et al., 1997c).

\section{Visits to the Audouin's gull subcolonies}

Laying dates of Audouin's gull eggs were determined by visiting the subcolonies every second or third day. The fate of the eggs was monitored by visiting Audouin's gull subcolonies after the laying period from about one to three time a week over the incubation period by recording the nest contents.

\section{RESULTS}

Yellow-legged gulls showed a decreasing proportion of birds present in the colony site during the morning and an increase during the evening (González-Solís et al., 1999). However, some individuals left the colony before dawn. The proportion 


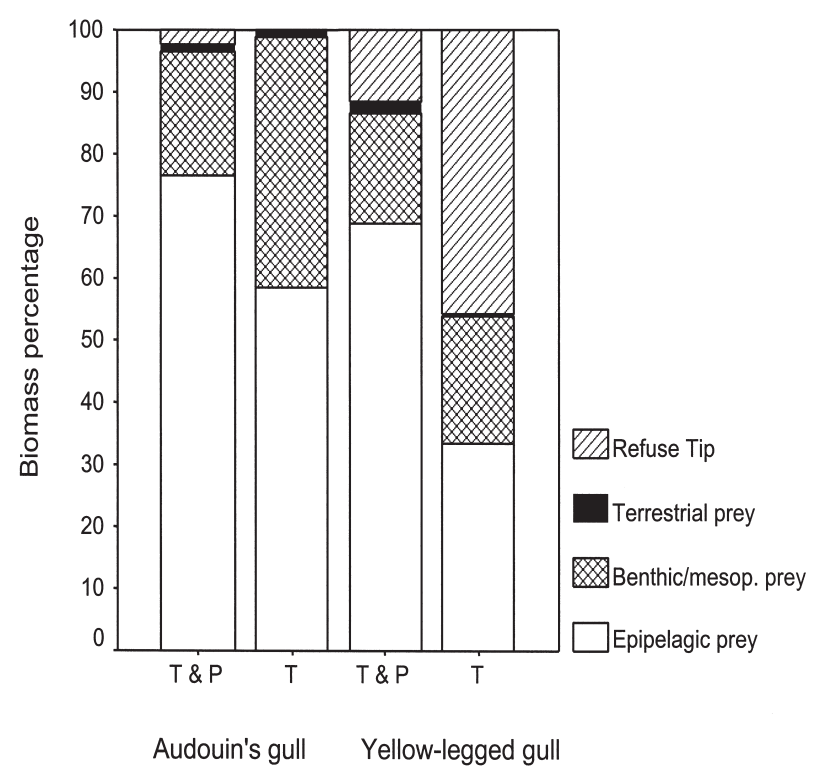

FIG. 2. - Diet composition (\% biomass) of Audouin's gull and yellow-legged gull (chick regurgitates), according to the activity of commercial fisheries. $\mathrm{T} \& \mathrm{P}=$ Trawler and purse seine operating. $\mathrm{T}=$ Only trawlers operating. Epipelagic prey $=$ mostly clupeoids collected in association with purse seine activity or by themselves. Terrestrial prey $=$ arthropods. Benthic/mesopelagic $=$ prey collected from trawler discard. Refuse tip $=$ waste food collected in refuse dumps.

of birds away from the colony in the morning was higher when purse-seine boats operated the preceding night than when boats did not operate, although the difference was not statistically significant. Activity patterns of Audouin's gulls showed no consistent diurnal effects. There was no evidence that the purse-seine fleet influenced the activity patterns of Audouin's gulls. However, significantly higher

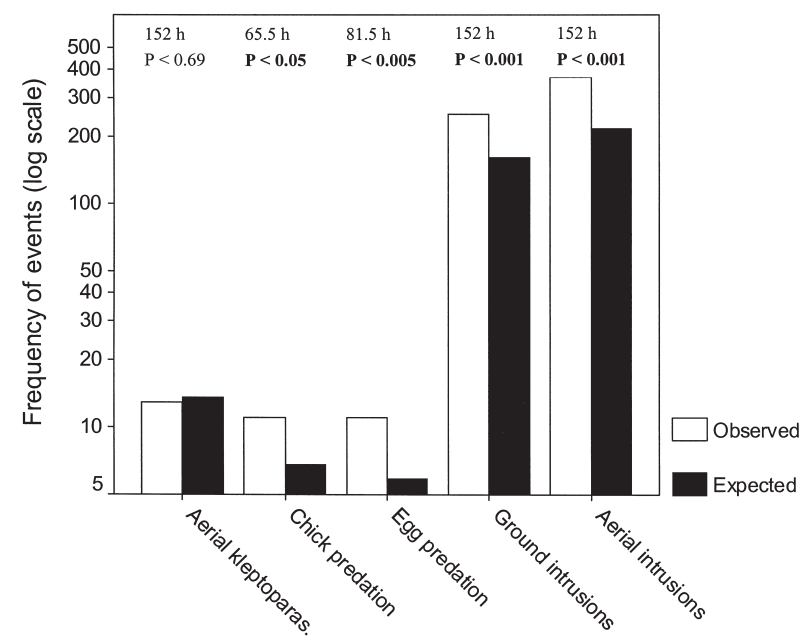

FIG. 3. - Number of interactions observed and expected between yellow-legged gulls and Audouin's gulls on the days without sardine catches, according to the hypothesis of no relationship with purse-seine activity. Above the bars, number of hours observed for each type or interaction (including days with sardine catches) and $\chi^{2}$ probability are shown. Chick predation includes successful and unsuccessful attempts only during the period overlapping with the presence of yellow-legged gull fledgings. numbers of Audouin's gulls remained at their breeding grounds on days following purse-seine activity. Since trawlers operate all year round and do not follow any particular time-table, it was not possible to detect any change in the activity patterns of gulls linked to this fishery.

When purse-seine fisheries did not operate, yellow legged-gulls exploited waste food from refuse tips (44\% in biomass), epipelagic fish (32\%), benthic or mesopelagic fish from trawler discards $(20 \%)$ and other secondary preys such as insects and cephalopods (Fig. 2). In contrast, Audouin's gulls fed mainly on epipelagic fish (57\%) and secondarily on fish from trawler discards (40\%). When purseseine fisheries operated, yellow legged-gulls increased the consumption of epipelagic fish from 32 to $63 \%$ and Audouin's gull from 57 to $73 \%$ (Fig. 2). Although 227 regurgitates were analysed, we found no remains of Audouin's gull chicks.

Among the five different types of interactions considered, flyovers of yellow-legged gulls on
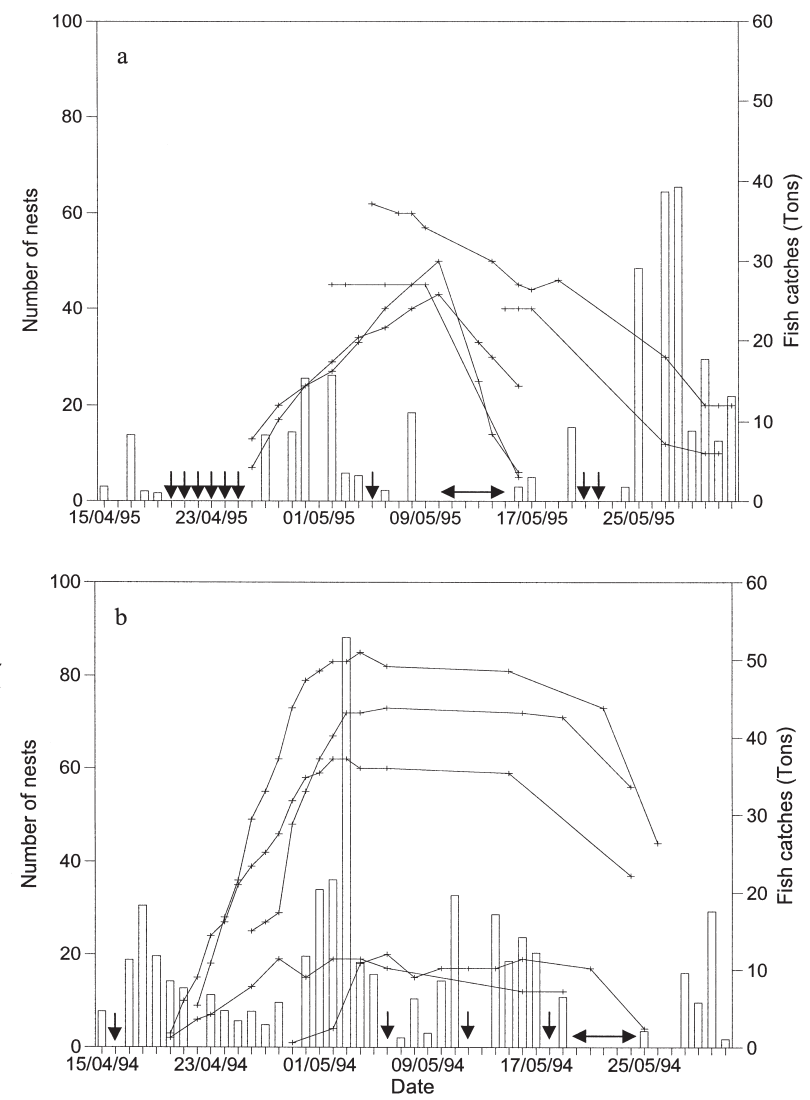

FIG. 4. - Number of Audouin's gull nests with eggs (with the progress of the incubation) at several subcolonies on the Chafarinas Islands in (a) 1995 and (b) 1994, in relation to fish landed by the purse-seine fleet at the Ras el Ma harbour (bars). Absence of fish catches indicates that purse-seine boats did not operate the preceding night. Vertical arrows indicate bad weather conditions. Horizontal arrows indicate local feasts, when neither purse-seine boats nor trawlers operated. 
Audouin's gull subcolonies, ground intrusions, egg predation, and chick predation were significantly more frequent during days without purse-seine activity in the preceding night than when this fishery operated (Fig. 3). However, aerial kleptoparasitism did not show significant differences in frequency according to the activity of purse-seine boats. Additionally, we found an increased chance that an aerial intrusion would elicit an agonistic response by Audouin's gulls on days without sardine catches compared to days with catches.

Changes in the numbers of Audouin's gull nests over the incubation period are shown in Figures 4a and 4b, for 5 subcolonies in both 1994 and 1995. In both years, a sharp decrease in the numbers of nests can be observed just after the holy lamp festival.

\section{DISCUSSION}

Patterns of activity of yellow-legged and Audouin's gulls clearly differed (González-Solís et al., 1999). Yellow-legged gulls were mainly diurnal, though some birds left the colony before dawn. The pre-dawn activity of gulls was probably related to purse-seine activity, since yellow-legged gulls exploit the last catches of purse-seine fisheries just before dawn as well as the small amount of offal discharged by this fishery when returning to the harbour (personal observations). Activity patterns of Audouin's gulls showed no consistent diurnal effects, suggesting that adults foraged during the day or night. Changes in the activity cycle of Audouin's gulls in relation to the activity of the purse-seine fisheries could not be detected, but the fact that higher numbers of Audouin's gulls remained at their breeding grounds on days following purse-seine activity suggests that gulls did take advantage of this fishery the night before.

Diet composition assessed from chick regurgitates differed substantially between the two gull species on the days when purse-seine fishery did not operate (González-Solís et al., 1997a). In such days, yellow-legged gulls fed mainly on waste food from refuse tips, whereas Audouin's gulls fed chiefly on epipelagic fish. Conversely, when purse-seine boats operated, yellow-legged and Audouin's gulls showed a clear overlap in diet composition, largely because both species substantially increased the proportion of epipelagic fish in their diet. These results suggest that feeding in association with purse-seine boats is a profitable strategy for both species. Thus, when purse-seine fisheries operate, both species of gulls take advantage of this resource, resulting in an important overlap in their diet, but when this resource is not available the two species largely segregate their diet, probably resulting in a reduced competition for food resources.

The activity of purse-seine fisheries influenced the predatory interactions between yellow-legged and Audouin's gulls. All interactions, except aerial kleptoparasitism, were significantly more frequent during days without purse-seine activity in the preceding night than when this fishery operated. Moreover, aerial intrusions of yellow-legged gulls to the Audouin's gull subcolonies on days without sardine catches showed a higher chance of eliciting an agonistic response by Audouin's gulls compared to days with catches. Assuming that agonistic responses of Audouin's gulls to overflying yellow-legged gulls reflect the intensity of predation pressure, we can presume that Audouin's gulls somehow perceived an increased risk of having their nest predated after a night without purse-seine activity. In summary, conditions of reduced food availability when the purseseine fishery did not operate resulted in the increase of predation pressure by yellow-legged gulls upon eggs and chicks of Audouin's gulls.

On several occasions predation attempts were performed by yellow-legged gulls breeding at the edge of Audouin's gull subcolonies (personal observation), suggesting a specialisation of this behaviour by a few individuals. In addition, no remains of Audouin's gull chicks were found among all regurgitates analysed, supporting the idea that chick predation is a rare event at the population level, but mainly performed by some specialised individuals.

Taking into account that at least $50 \%$ in biomass of the resources obtained by yellow-legged gulls was associated with the activity of fisheries, days when not only purse-seine boats but also trawlers cancelled their operations can be considered as representing severe food shortage conditions. This situation, however, only occurred occasionally, since trawlers stop operating only in very bad weather conditions, which is unusual during the breeding season of gulls. The unique exception to this rule is the holy lamb festival celebrated in Muslim countries such as Morocco, when all fisheries stop. This religious festival lasts about a week and each year is celebrated about 10 days earlier than the year before. During the study period, this celebration coincided with the end (1994) and with the middle 
(1995) of the incubation period of the Audouin's gull. In both years, the festival period coincided with intense predation on Audouin's gull eggs, resulting in a marked reduction in numbers of eggs in several subcolonies (Figs. 4a, b). At the Chafarinas Islands the only alternative potential egg predator apart from yellow-legged gulls are rats but all available evidence suggests that at this colony rats only scavenge on broken eggs (Prieto et al., in press). Thus, the evidence reported above strongly suggests that severe food shortage due to absence of fishery activities induced an intense predation by yellow-legged gulls upon nest of Audouin's gulls. Fortunately, on most occations this festivity is celebrated out of the Audouin's gull breeding season.

In summary, competence for food between the two species at the Chafarinas Islands is mainly limited to the periods when resources made available by fishery activities are abundant. When fisheries do not operate, predation of yellow-legged gulls on eggs and chicks of Audouin's gulls can result in a decrease in productivity of Audouin's gulls. This interaction reveals a novel socio-ecological link between gulls, fisheries and local feasts at the Chafarinas Islands.

\section{ACKNOWLEDGEMENTS}

This review is based on the work of many people. I would like to thank Xavier Ruiz and Lluis Jover for guidance during the years of my $\mathrm{PhD}$. I am indebted to my colleagues of voyage, especially Daniel Oro and Vittorio Pedrocchi, Joan Carles Abella and personnel of GENA (Jorge F. Orueta, Tomás Gómez, Yolanda Aranda, Gerardo García, Gonzalo Martínez) and ICONA for their help at different stages. I am also grateful to Georgina Alvarez and the "Plan coordinado para la gaviota de Audouin", GENA and the University of Barcelona for providing data on gull census at Chafarinas Islands. I thank $\mathrm{S}$. Wanless for helpful comments on the manuscript.

\section{REFERENCES}

Alvarez, G. - 1992. Conservation programme for Audouin's gull in the Chafarinas Islands. Avocetta, 16: 63-66.

Arcos, J.M., D. Oro and D. Sol. - 2001. Competition between the yellow-legged gull Larus cachinnans and Audouin's gull Larus audouinii associated with commercial fishing vessels: the influence of season and fishing fleet. Mar. Biol., 139: 807-816.

Arcos, J.M. and D. Oro. - 2002. Significance of nocturnal purseseine fisheries for seabirds: a case study off the Ebro Delta (NW Mediterranean). Mar. Biol., 141: 277-286.

Bosch, M., D. Oro, F.J. Cantos and M. Zabala. - 2000. Short-term effects of culling on the ecology and population dynamics of the yellow-legged gull. J. Appl. Ecol., 37: 369-385.

Bosch, M., D. Oro and X. Ruiz. - 1994. Dependence of Yellowlegged Gulls (Larus cachinnans) on food from human activity in two Western Mediterranean colonies. Avocetta, 18: 135-139.

González-Solís, J., D. Oro, L. Jover, X. Ruiz and V. Pedrocchi. 1997a. Trophic niche width and overlap of two sympatric gulls in the southwestern mediterranean. Oecologia, 112: 75-80.

González-Solís, J., D. Oro, V. Pedrocchi, L. Jover and X. Ruiz. 1997b. Bias associated with diet samples in Audouin's gulls. Condor, 99: 773-779.

González-Solís, J., X. Ruiz and L. Jover. - 1997c. Influence of food availability on interactions between Larus cachinnans and $L$ audouinii. Can. J. Zool., 75: 719-724.

González-Solís, J., X. Ruiz and L. Jover. - 1999. Fisheries and daily activity cycles of Audouin's Larus audouinii and Yellowlegged Gulls L. cachinnans breeding at the Chafarinas Islands (Moroccan coast). Vogelwarte, 40: 52-56.

Munilla, I. - 1997. Henslow's swimming crab (Polybius henslowii) as an important food for yellow-legged gulls (Larus cachinnans) in NW Spain. ICES J. Mar. Sci., 54: 631-634.

Oro, D. - 1995. The influence of commercial fisheries in daily activity of Audouin's Gull Larus audouinii in the Ebro Delta, NE Spain. Ornis Fennica, 72: 154-158.

Oro, D. - 1998. Larus audouinii Audouin's Gull. In: BWP Update, pp. 47-61. Oxford University Press,

Oro, D., X. Genovart, X. Ruiz, J. Jimenez and J. Garcia-Gans. - 1996a. Differences in diet, population size and reproductive performance between two colonies of Audouin's gull Larus audouinii affected by a trawling moratorium. J. Avian Biol., 27: 245-251.

Oro, D., L. Jover and X. Ruiz. - 1996b. Influence of trawling activity on the breeding ecology of a threatened seabird, Audouin's gull Larus audouinii. Mar. Ecol. Prog. Ser., 139: 19-29.

Oro, D., X. Ruiz, L. Jover, V. Pedrocchi and J. González-Solís. 1997. Diet and adult time budgets of Audouin's Gull Larus audouinii in response to changes in commercial fisheries. Ibis, 139: 631-637.

Pedrocchi, V., D. Oro, J. González-Solís, X. Ruiz and L. Jover. 2002. Differences in diet between the two largest breeding colonies of Audouin's gulls: the effect of fishery activities. Sci. Mar., 66: 313-320.

Prieto, J., J. González-Solís, X. Ruiz and L. Jover. - (in press). Can rats prey on gull eggs? An experimental approach. Biodiv. Conserv.

Vidal, E., F. Medail and T. Tatoni. - 1998. Is the yellow-legged gull a superabundant bird species in the Mediterranean? Impact on fauna and flora, conservation measures and research priorities. Biodiv. Coserv., 7: 1013-1026.

Witt, H. H., J. Crespo, E. De Juana and J. M. Varela. - 1981. Comparative feeding ecology of Audouin's gull Larus audouinii and the herring gull L. argentatus in the Mediterranean. Ibis, 123: 519-526. 